\title{
Article
}

\section{Benzimidazole Derivatives as New and Selective Inhibitors of Arginase from Leishmania mexicana with Biological Activity against Promastigotes and Amastigotes}

\author{
Irene Betancourt-Conde ${ }^{1}$, Claudia Avitia-Domínguez ${ }^{1, *}$, Alicia Hernández-Campos ${ }^{2}$, Rafael Castillo ${ }^{2}$, \\ Lilián Yépez-Mulia $^{3}{ }^{\mathbb{D}}$, Jesús Oria-Hernández ${ }^{4}$ (D), Sara T. Méndez ${ }^{4}\left(\mathbb{D}\right.$, Erick Sierra-Campos ${ }^{5}$ (D), \\ Mónica Valdez-Solana ${ }^{5}$, Siseth Martínez-Caballero ${ }^{6,+}$, Juan A. Hermoso ${ }^{6}$, Antonio Romo-Mancillas ${ }^{7}$ (D) and \\ Alfredo Téllez-Valencia ${ }^{1, *(D)}$
}

1 Facultad de Medicina y Nutrición, Universidad Juárez del Estado de Durango, Av. Universidad y Fanny Anitúa S/N, Durango 34000, Mexico; betancourtirene@gmail.com

2 Departamento de Farmacia, Facultad de Química, Universidad Nacional Autónoma de México, Mexico City 04510, Mexico; hercam@unam.mx (A.H.-C.); rafaelc@unam.mx (R.C.)

3 Unidad de Investigación Médica en Enfermedades Infecciosas y Parasitarias, Unidad Médica de Alta Especialidad-Hospital de Pediatría, Centro Médico Nacional Siglo XXI, Instituto Mexicano del Seguro Social, Mexico City 06720, Mexico; lilianyepez@yahoo.com

4 Laboratorio de Bioquímica-Genética, Instituto Nacional de Pediatría, Secretaría de Salud, Mexico City 04530, Mexico; jesus.oria.inp@gmail.com (J.O.-H.); saratme@hotmail.com (S.T.M.)

check for updates

Citation: Betancourt-Conde, I.;

Avitia-Domínguez, C.;

Hernández-Campos, A.; Castillo, R.; Yépez-Mulia, L.; Oria-Hernández, J.; Méndez, S.T.; Sierra-Campos, E.; Valdez-Solana, M.; Martínez-Caballero, S.; et al. Benzimidazole Derivatives as New and Selective Inhibitors of Arginase from Leishmania mexicana with Biological Activity against Promastigotes and Amastigotes. Int. J. Mol. Sci. 2021, 22, 13613. https:// doi.org/10.3390/ijms222413613

Academic Editor: Ivana Pibiri

Received: 1 December 2021

Accepted: 16 December 2021

Published: 19 December 2021

Publisher's Note: MDPI stays neutral with regard to jurisdictional claims in published maps and institutional affiliations.

Copyright: (c) 2021 by the authors. Licensee MDPI, Basel, Switzerland. This article is an open access article distributed under the terms and conditions of the Creative Commons Attribution (CC BY) license (https:/ / creativecommons.org/licenses/by/ $4.0 /)$.
5 Facultad de Ciencias Químicas, Universidad Juárez del Estado de Durango, Av. Artículo 123 S/N Fracc Filadelfia, Gómez Palacio 35010, Mexico; ericksier@ujed.mx (E.S.-C.); valdezandyval@gmail.com (M.V.-S.)

6 Departamento de Cristalografía y Biología Estructural, Instituto Química-Física Rocasolano, Consejo Superior de Investigaciones Científicas, 28006 Madrid, Spain; siseth.martinez@iquimica.unam.mx (S.M.-C.); xjuan@iqfr.csic.es (J.A.H.)

7 Laboratorio de Diseño Asistido por Computadora y Síntesis de Fármacos, Facultad de Química, Universidad Autónoma de Querétaro, Querétaro 76010, Mexico; ruben.romo@uaq.mx

* Correspondence: claudia.avitia@ujed.mx (C.A.-D.); atellez@ujed.mx (A.T.-V.); Tel.: +52-618-812-1687 (A.T.-V.)

† Current Address: Departamento de Química de Biomacromoléculas, Instituto de Química, Universidad Nacional Autónoma de México, Mexico City 04510, Mexico.

Abstract: Leishmaniasis is a disease caused by parasites of the Leishmania genus that affects 98 countries worldwide, 2 million of new cases occur each year and more than 350 million people are at risk. The use of the actual treatments is limited due to toxicity concerns and the apparition of resistance strains. Therefore, there is an urgent necessity to find new drugs for the treatment of this disease. In this context, enzymes from the polyamine biosynthesis pathway, such as arginase, have been considered a good target. In the present work, a chemical library of benzimidazole derivatives was studied performing computational, enzyme kinetics, biological activity, and cytotoxic effect characterization, as well as in silico ADME-Tox predictions, to find new inhibitors for arginase from Leishmania mexicana (LmARG). The results show that the two most potent inhibitors (compounds 1 and 2) have an $\mathrm{I}_{50}$ values of $52 \mu \mathrm{M}$ and $82 \mu \mathrm{M}$, respectively. Moreover, assays with human arginase 1 (HsARG) show that both compounds are selective for LmARG. According to molecular dynamics simulation studies these inhibitors interact with important residues for enzyme catalysis. Biological activity assays demonstrate that both compounds have activity against promastigote and amastigote, and low cytotoxic effect in murine macrophages. Finally, in silico prediction of their ADME-Tox properties suggest that these inhibitors support the characteristics to be considered drug candidates. Altogether, the results reported in our study suggest that the benzimidazole derivatives are an excellent starting point for design new drugs against leishmanisis.

Keywords: leishmaniasis; arginase; virtual screening; enzyme inhibition; molecular dynamics; benzimidazole derivatives 


\section{Introduction}

Leishmaniasis is a neglected tropical disease transmitted by sandfly vector (Phlebotomus or Lutzomyia) via anthroponotic or zoonotic cycles [1]. The three main forms of leishmaniasis include cutaneous (CL), mucosal (MCL) and visceral leishmaniasis (VL) [2]. This disease affects 98 countries, and it is estimated that approximately 2 million of new cases occur each year and more than 350 million people are at risk [3].

The first line treatment against the leishmaniasis consist in sodium stibogluconate (Pentostam) and meglumine antimoniate (Glucantime) [4]. Nevertheless, their use is limited due to their toxicity and the apparition of resistance strains [5]. Pentamidine and Amphotericin B are used as second line drugs, but as well as antimonials, their use is limited due to its toxicity and the parasite resistance [6,7]. Miltefosine is the only existing oral drug to the treatment of leishmaniasis, however, its use has not been satisfactory due to the potential parasite resistance, also it is necessary to continue with its pharmacovigilance [8]. Other proposed topical treatments involve Rifamycin and novel drug-delivery systems that may help the diffusion and the efficacy [9]. Recently, a combined therapy strategy has been used to overcome the resistance in bacteria, nevertheless, this has been poorly tested in leishmaniasis and it must be established for each species of Leishmania [10]. Therefore, it is important to look for new drugs against leishmaniasis.

In this regard, because of their central role in proliferation, differentiation, and antioxidant mechanisms in Leishmania, enzymes for polyamines (PAs) biosynthesis are considered attractive drug targets to develop new drugs against leishmaniasis. Moreover, this pathway is linked with the trypanothione pathway and its enzymes are structurally different from their homologous in human [11,12]. The PAs biosynthesis pathway starts with the synthesis of the precursor L-ornithine, catalyzed by arginase (ARG) through the hydrolysis of L-arginine. Afterwards, ornithine is transformed to putrescine by ornithine decarboxylase. Finally, spermidine synthase converts putrescine in spermidine, which is one of the precursors for trypanothione biosynthesis [12-14]. One of the enzymes that has been received a special interest is arginase.

Structurally, arginase from Leishmania mexicana (LmARG) is a homotrimer stabilized by intermolecular ionic interactions and hydrogen bonds. This enzyme belongs to $\alpha / \beta$ family and is composed by eight-stranded $\beta$-sheet flanked on both sides by $\alpha$-helices. Arginase is a metalloenzyme that requires of two manganese ions for its enzyme activity arrayed as a binuclear $\mathrm{Mn}^{+2}$ center located at the bottom of a $\sim 15 \AA$-deep active site cleft coordinated in an octahedral arrangement. The catalytic residues are Glu288 which participates in substrate recognition, whilst Asp141 stabilizes the hydroxide ion, and His139 that is a proton shuttle [15].

Despite of their similar folding with the human arginase 1 (HsARG), some differences are shown in the tertiary structure. Three regions change in the LmARG, first, a new helix was found (Gly62-Ser71), which corresponds to a loop in the HsARG. Also, the loop formed by residues Leu161-Cys172, and helix formed by Ile219-Val230 in HsARG (LmARG numeration) shows a different conformation in LmARG. Finally, differences in the intermolecular interactions that stabilize the homotrimer were found [15].

On the other hand, arginase-knockout mutants from L. mexicana, L. amazonensis and L. major demonstrated the importance of this enzyme since its absence made parasites auxotrophic to polyamines $[13,16,17]$. Actually, there are several arginase inhibitors reported in different Leishmania species, in the case of L. amazonensis (LaARG), [1,2,4]triazolo [1,5-a]pyrimidine derivatives [17], flavanols [18,19], and cinnamide derivatives [20] had been reported, with the best compounds showing a mixed type inhibition and a $\mathrm{I}_{50}$ in the micromolar range. In L. infantum (LiARG), natural phenolic derivatives [21] and chalcone derivatives [22] have been reported as enzyme inhibitors. In LmARG, substrate or transition state analogues inhibited the enzyme [23,24]. Here, the most potent compounds (ABH, BEC and NOHA) inhibited LmARG in a competitive way, with Ki values of 1.3-85 $\mu \mathrm{M}$, however, they were not selective to LmARG [23]. Furthermore, $\alpha, \alpha$-disubstituted boronic amino acid inhibitors were capable to inhibit LmARG showing a special type of binding [24]. 
In this work, we applied a virtual screening strategy from our in-house benzimidazole derivatives chemical library to find new and selective LmARG inhibitors. Kinetic and molecular dynamics characterization studies were performed, as well as their biological activity against the two stages of the parasite and their cytotoxic effect in murine macrophages. Moreover, its selectivity against HsARG and a prediction of their ADME-Tox properties were also made.

\section{Results}

\subsection{Virtual Screening and LmARG Inhibition}

With the aim to find new LmARG inhibitors that recognize the active site of the enzyme, we performed a virtual screening, using molecular docking, of our in-house library of 450 benzimidazole derivatives using the crystal structure of LmARG (PDB ID: 4IU0). The ligands were ranked according to their respective docking scores.

The fifty molecules with the highest score were chosen for inhibition studies. According to data, 33 compounds inhibited LmARG in a range of $8-100 \%$ at a concentration of $200 \mu \mathrm{M}$ (Table S1). The ten compounds that induced the highest LmARG inhibition are shown in Table 1. As can be observed, compounds $\mathbf{1}$ and $\mathbf{2}$ are the most effective against the enzyme at the evaluated concentration. Nonetheless, some interesting structural activity relationships can be analyzed from these data. The changing of a methylcarbamate in position 2 of the benzimidazole nucleus by an acetyl group, reduce almost $50 \%$ the inhibitory potency (compound 1 vs. 4). Additionally, only changing the chloride from position 5 to 6 diminishes the inhibition $60 \%$ (compound 1 vs. 8). In the same context, substituting the chloride by a larger and hydrophobic group such as propylthio, has the same effect (compound 1 vs. 9). On the other hand, the change of carboxamide in position 5 by a piperazine group provokes more than $50 \%$ lost in potency (compound 2 vs. 6). Additionally, when the size of the R group attached to sulfur, at position 2, is larger and with a greater degree of freedom, the activity decreases 40 or $60 \%$ in comparison with a small group (2 vs. 3 and 7 ).

Table 1. Benzimidazole derivatives with the highest inhibition of recombinant LmARG.

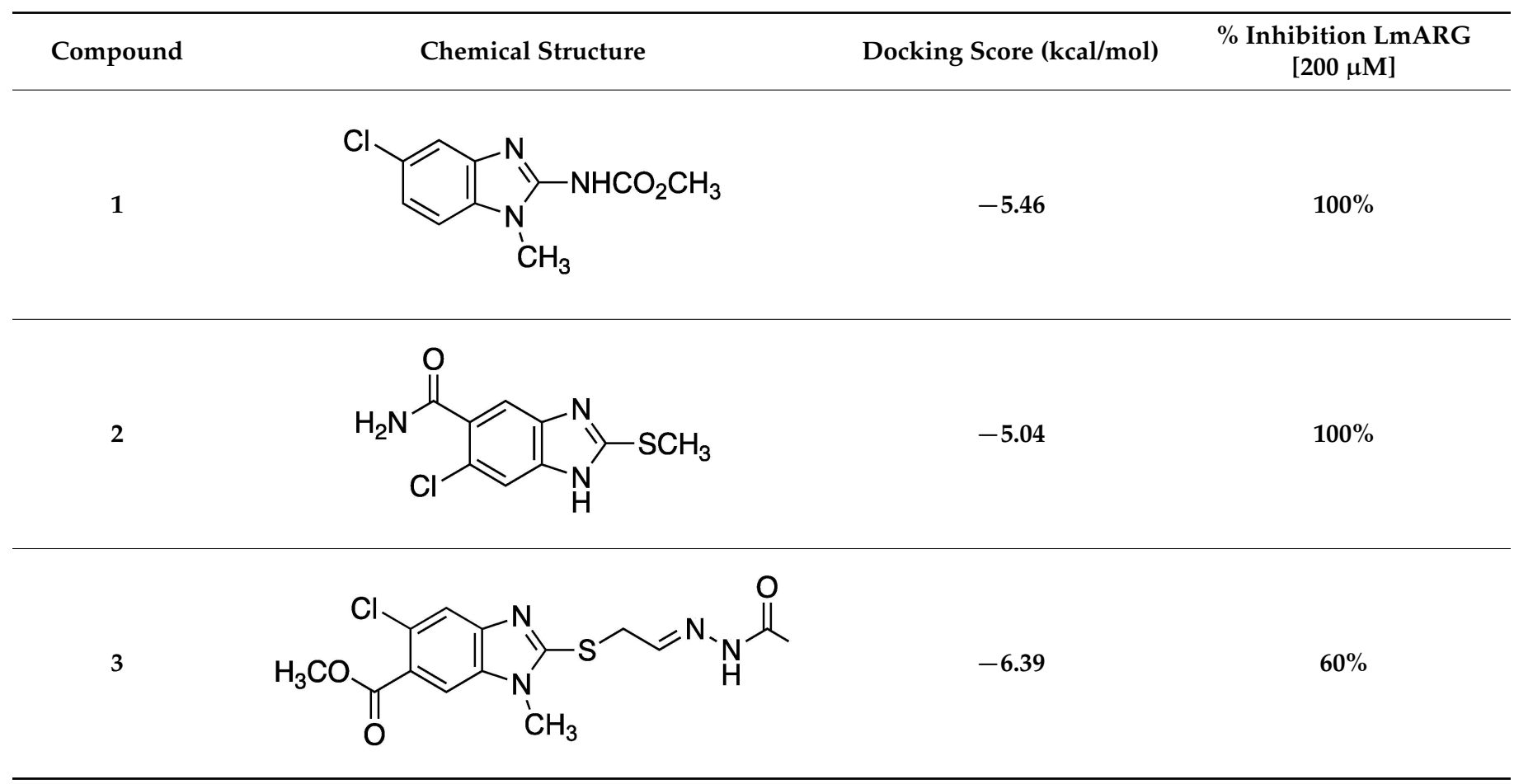


Table 1. Cont.

Compound

6<smiles>CSc1nc2cc(N3CCNCC3)c(Cl)cc2[nH]1</smiles><smiles>COC(=O)c1cc2c(cc1Cl)nc(SCCNC(=N)N)n2C</smiles><smiles>CC(=O)Nc1nc2ccc(Cl)cc2n1C</smiles><smiles>CC(=O)c1nc2ccc(Cl)cc2n1C</smiles>

To continue with kinetic characterization, the concentration that inhibits $50 \%$ enzyme activity $\left(\mathrm{I}_{50}\right)$ was determined for the two most potent compounds ( $\mathbf{1}$ and $\left.\mathbf{2}\right)$. The data show that compounds 1 and 2 have an $\mathrm{I}_{50}$ value of $52 \mu \mathrm{M}$ and $82 \mu \mathrm{M}$, respectively (Figure 1). Both compounds show a cooperative behavior, this fact suggests that more than one molecule are required to inhibit the enzyme $[25,26]$. 

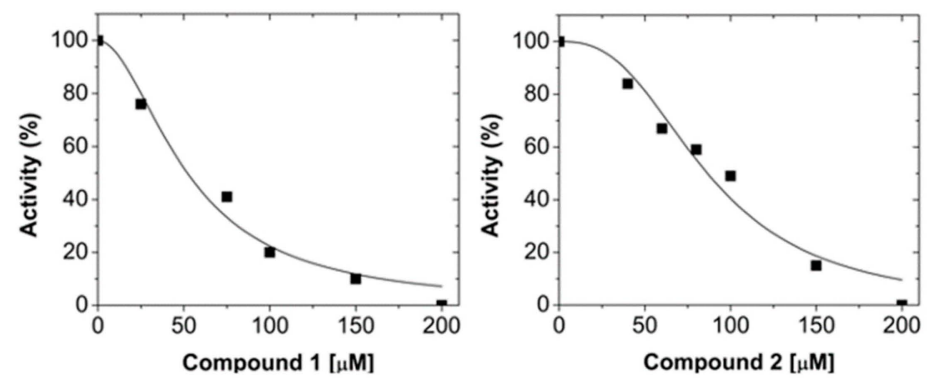

Figure 1. Inhibition kinetics of recombinant LmARG by compounds $\mathbf{1}$ and 2.

\subsection{Human Arginase 1 Inhibition}

Nowadays, one of the principal concerns in LmARG inhibitors design is their selectivity against human arginase 1 (HsARG) [23,27]. Therefore, the potential inhibitory activity of both compounds against recombinant HsARG was determined. The results show that at the highest concentration possible to be tested $(1 \mathrm{mM})$ none of the compounds inhibit completely the enzyme (Figure 2), whilst $100 \%$ inhibition of recombinant LmARG was achieved when compounds $\mathbf{1}$ and $\mathbf{2}$ were used five times less concentrated (Table 1 and Figure 1). Therefore, this data demonstrate that compounds $\mathbf{1}$ and $\mathbf{2}$ are selective to the enzyme from parasite. As far as we know, this is the first study that reports LmARG selective inhibitors.
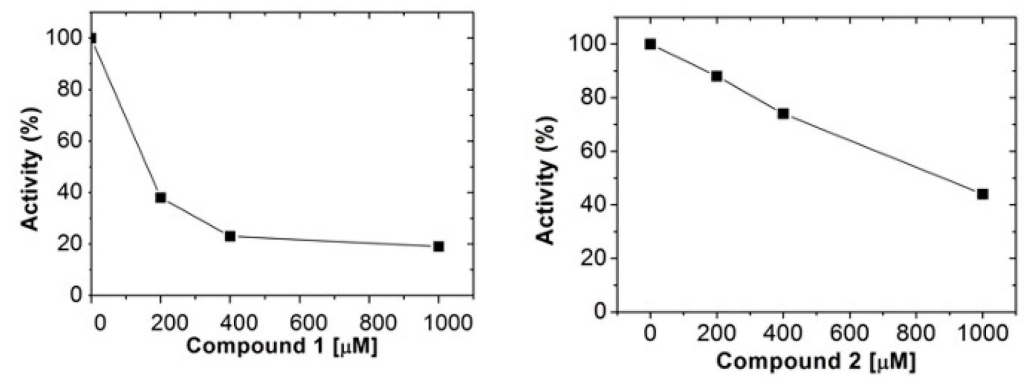

Figure 2. Inhibition kinetics of recombinant HsARG by compounds $\mathbf{1}$ and $\mathbf{2}$.

\subsection{Molecular Dynamics}

Once the kinetic studies were caried out, it was important to know how these inhibitors interact with the enzyme. To investigate the binding mode of both compounds in LmARG, molecular dynamics simulations of $30 \mathrm{~ns}$ were performed. First, to explore the dynamic stability of systems, Root Mean Square Deviation (RMSD) was analyzed in Apo-LmARG and the complexes (Figure 3). The observed deviation through the simulation time was $0.15 \mathrm{~nm}$ approximately, which indicates that the systems were stable throughout the simulation.

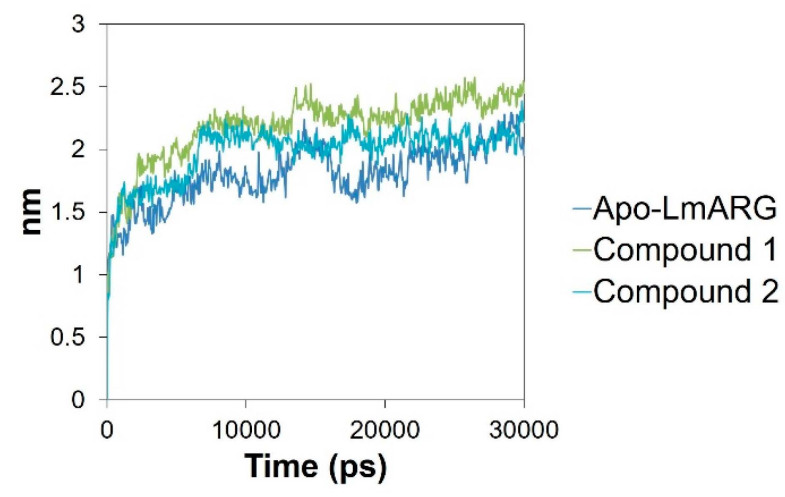

Figure 3. Root Mean Square Deviation analysis of $\mathrm{C} \alpha$ in the Apo-LmARG and the respective complexes. 
Subsequently, the Root Mean-Square Fluctuation (RMSF) between Apo-LmARG, and each LmARG-compound complex was analyzed to visualize local changes along the protein chain (Figure 4). Large variations in some regions were observed, therefore, an ANOVA analysis was realized between Apo-LmARG and both complexes, getting p values of 0.0001 ( $p<0.05$ significative) in both cases. These results indicate that the binding of the compounds cause the fluctuations observed.

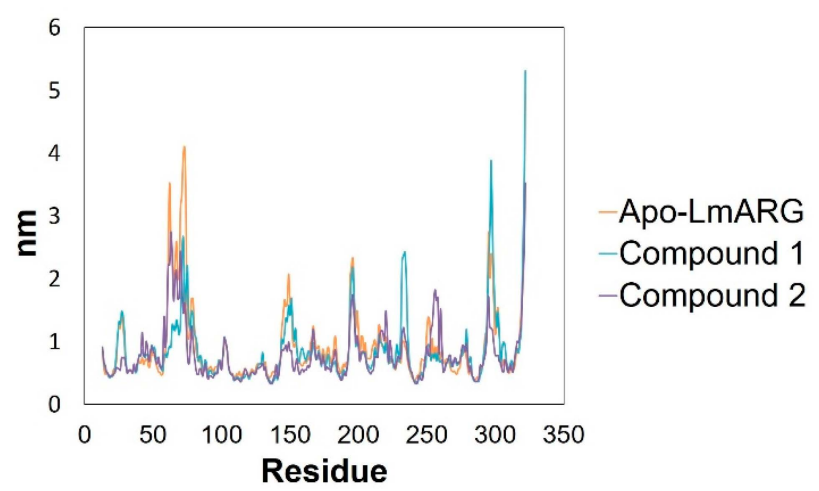

Figure 4. Root Mean Square Fluctuation analysis of $\mathrm{C} \alpha$ in the Apo-LmARG and the respective complexes.

The regions with the highest variations correspond to diverse protein loops. Arginases possess various important loops that participate in the opening of the substrate binding site or enclosing the active site cavity. Therefore, an analysis of the residues that forms those loops in Apo-LmARG and the two complexes was performed. The data show that in both complexes, the loops that participate in the binding of arginine carboxylic acid, as well as the primary amine binding region, were the loops that show less flexibility in the C $\alpha$ fluctuations (Figure 5). This behavior was like that reported by Mortier et al. 2017, where it was observed, in the comparison of $C \alpha$ in the RMSF, that there were larger movements with Apo-LmARG than with arginase-ligand complexes, indicating that the arginase binding site is a highly flexible site [27].

a) 2.5
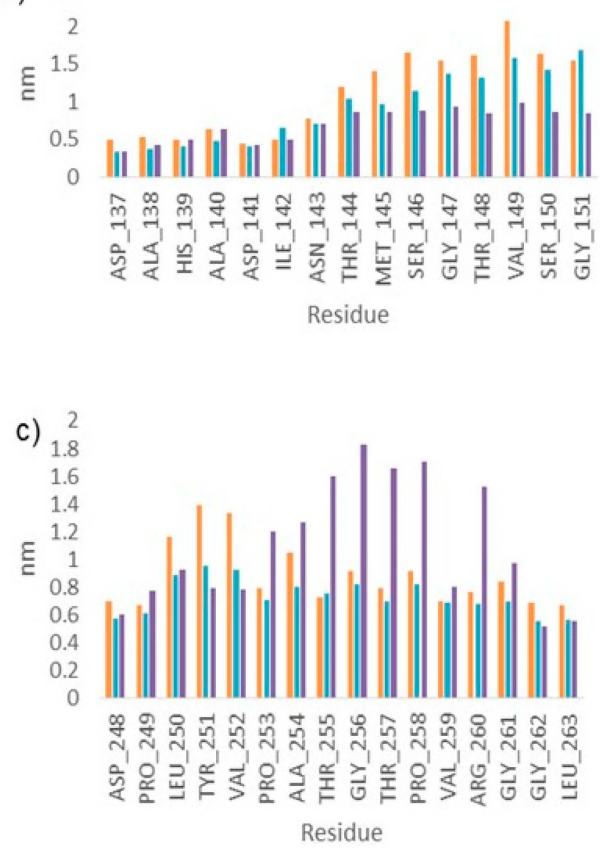
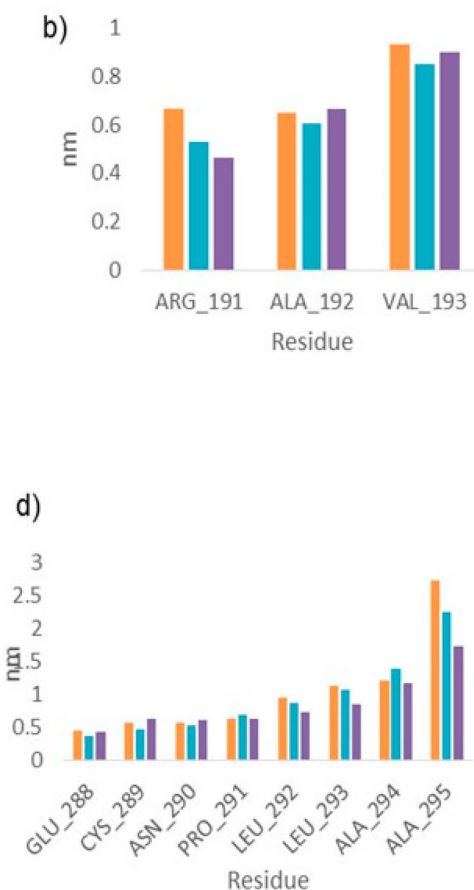

Figure 5. Root Mean Square Fluctuation analysis of C $\alpha$ in (a) loop 1, (b) loop 2, (c) loop 3, and (d) loop 4. Apo-LmARG (orange), LmARG-compound 1 (blue), LmARG-compound 2 (violet). 


\subsection{LmARG-Inhibitor Interactions}

In order to understand how these inhibitors behaved along MD simulation, a detailed analysis of their interactions was carried out. Compound $\mathbf{1}$ interacts only in the first $10 \mathrm{~ns}$ through a hydrogen bound with Asn143, and at the end of the simulation makes another hydrogen bound with Glu 197. Moreover, there are also Van der Waals interactions with His139, Ala140, Val149, His154, Ala192, Val193, Ile200, Met211, Val259, Leu263, and ionic interactions with Asp137, Asp141, Asp243, Asp245 and His139 (Figure 6a).

On the other hand, compound 2 forms a pi-pi interaction in the first $10 \mathrm{~ns}$ between the His154 and the benzimidazole ring, in addition to a hydrogen bond interaction between the Asp141 and the $\mathrm{NH}$ of the benzimidazole ring, interestingly, it was maintained during all simulation time. Moreover, there are Van der Waals interactions with His139 and His154, and ionic interactions with His114, Asp137, His139, Asp141, Asp243, Asp245, and Glu288 (Figure 6b).

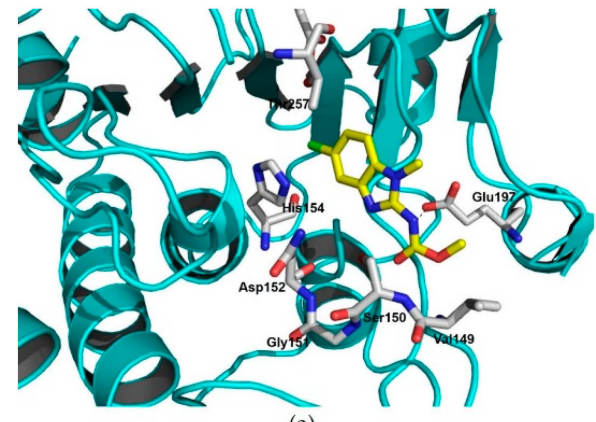

(a)

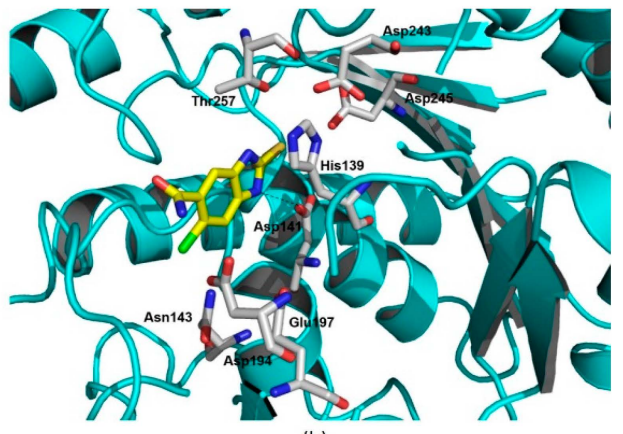

(b)

Figure 6. Ligand interactions in LmARG-inhibitor complexes after $30 \mathrm{~ns}$ of MD simulation. (a) compound 1 and (b) Compound 2. Both inhibitors are represented as yellow sticks for the $\mathrm{C}$ atoms. Relevant residues surrounding the inhibitor are depicted as capped sticks and labeled. Predicted polar interactions (Glu197 and Asp141, respectively) depicted dashed lines.

\subsection{Biological Activity Evaluation and Cytotoxicity}

To continue the characterization of these inhibitors, an important issue was to investigate their biological activity. Therefore, they were tested for antileishmanial activity against promastigotes and amastigotes from L. mexicana. The results show that both compounds have leishmanicidal activity in the promastigote and in the intracellular amastigote. Compound 1 showed to be more active in both promastigote $\left(\mathrm{IC}_{50}=64 \mu \mathrm{M}\right)$ and amastigote $\left(\mathrm{IC}_{50}=32 \mu \mathrm{M}\right)$ than the Glucantime, nonetheless, it was less active than Amphotericin B and Miltefosine (Table 2). Regarding to cytotoxicity, both compounds have $\mathrm{CC}_{50}$ values $>417 \mu \mathrm{M}$ against murine macrophages J774.2 cell line and a selectivity index (SI) higher than the reference drugs Glucantime, Amphotericin B and Miltefosione. (Table 2).

Table 2. Leishmanicidal activities, cytotoxicity and selective index of compounds 1, 2 and reference drugs.

\begin{tabular}{|c|c|c|c|c|c|}
\hline \multirow{2}{*}{ Compound } & \multicolumn{2}{|c|}{$\mathrm{IC}_{50}(\mu \mathrm{M})$} & \multirow{2}{*}{$\mathrm{CC}_{50}(\mu \mathrm{M})$} & \multicolumn{2}{|c|}{ SI ${ }^{1}$} \\
\hline & Promastigotes & Amastigotes & & Promastigotes & Amastigotes \\
\hline 1 & 64 & 32 & $>417^{2}$ & 6.5 & 13 \\
\hline 2 & 132 & 101 & $>414^{2}$ & 3.1 & 4.1 \\
\hline Glucantime & 101 & 35 & $>273^{3}$ & 2.7 & 7.8 \\
\hline Amphotericin B & 0.89 & 1.3 & $7.4^{3}$ & 8.3 & 6.2 \\
\hline Miltefosine & 8.1 & 8.6 & $141^{3}$ & 17.4 & 2 \\
\hline
\end{tabular}

${ }_{1}^{1}$ The selectivity index (SI) was calculated as the ratio of cytotoxicity to biological activity $\left(\mathrm{SI}=\mathrm{CC}_{50} / \mathrm{IC}_{50}\right)$

2 The results show the maximum concentration evaluated in the experiments. ${ }^{3}$ Data obtained from Matadamas-

Martínez et al., 2019 [28]. 


\subsection{In Silico Physichemical and ADME-Tox Predictions}

In the first steps of drug design process the Drug-like properties of the studied molecules is an issue of interest. With this in mind, the physicochemical parameters and ADME-Tox properties of compounds $\mathbf{1}$ and $\mathbf{2}$ were predicted through an in silico study as described in methodology. The results show that both compounds fulfilled the Lipinski, Veber and Egan rules, suggesting that these molecules have a good oral biodisponibility (Table 3). Moreover, toxicity studies predict that any of these compounds should bind to proteins that have been associated with adverse reactions and toxic effects (Table 3). The oral toxicity prediction shows that compounds 1 and 2 would have a $\mathrm{LD}_{50}$ of $5050 \mathrm{mg} / \mathrm{kg}$ and $750 \mathrm{mg} / \mathrm{kg}$, respectively. Furthermore, compound 1 belongs to the toxicity class 6 which indicates that should be safe to use, while compound 2 belongs to the toxicity class 4 which indicates that it could be harmful but only if $>2000 \mathrm{mg} / \mathrm{kg}$ have been administered. Therefore, both molecules possess Drug-like properties and are likely to have good absorption and eventually do not show any toxic effects.

Table 3. In-silico predicted physicochemical parameters and ADME-Tox profiling of compounds 1 and 2.

\begin{tabular}{|c|c|c|}
\hline Descriptor & $\begin{array}{c}\text { Compound } \\
1\end{array}$ & $\begin{array}{c}\text { Compound } \\
2\end{array}$ \\
\hline $\mathrm{MW}^{1}$ & 239.66 & 241.7 \\
\hline $\log \mathrm{P}^{1}$ & 2.35 & 2.1 \\
\hline $\log \mathrm{D}^{1}$ & 2.63 & 2.03 \\
\hline $\log S w^{1}$ & -2.93 & -2.82 \\
\hline $\mathrm{tPSA}^{1}$ & 56.15 & 97.07 \\
\hline $\mathrm{RB}^{1}$ & 2 & 2 \\
\hline $\mathrm{HBD}^{1}$ & 1 & 3 \\
\hline $\mathrm{HBA}^{1}$ & 5 & 4 \\
\hline Lipinski's violations $^{1}$ & none & none \\
\hline Veber Rules $^{1}$ & Good & Good \\
\hline Egan Rules $^{1}$ & Good & Good \\
\hline $\mathrm{BBB}+{ }^{2}$ & 0.9584 & 0.9117 \\
\hline $\mathrm{HIA}+{ }^{2}$ & 0.9965 & 0.9819 \\
\hline $\mathrm{Caco}^{2}$ & 0.6531 & 0.5468 \\
\hline Lysosome $^{2}$ & 0.6217 & 0.6217 \\
\hline Predicted $\mathrm{LD}_{50}{ }^{3}$ & $5050 \mathrm{mg} / \mathrm{kg}$ & $705 \mathrm{mg} / \mathrm{kg}$ \\
\hline Predicted toxicity class ${ }^{3}$ & 6 & 4 \\
\hline Toxicity targets $^{3}$ & no binding & no binding \\
\hline
\end{tabular}

${ }^{1}$ Obtained in FAFDrugs4 server; MW, Molecular weight MW. LogP, logarithm of the partition coefficient $n-$ octanol/water; $\log D$ octanol water distribution coefficient; $\operatorname{logSw}$, intrinsic water solubility; tPSA, topological polar surface area; RB, rotable bonds; HBD, hydrogen bond donors; HBA, hydrogen bond acceptors. ${ }^{2}$ Obtained in ADMET-SAR server; BBB+, Blood-Brain Barrier; HIA+, Human Intestinal Absorption; Caco2, Caco2 Permeability. ${ }^{3}$ Obtained in ProTox server; Predicted toxicity class values ranged between 1 to 6,1 is toxic and 6 is safe. Toxicity targets were determined for: Adenosine A2A receptor, Adrenergic beta 2 receptor, Androgen receptor, Amine oxidase, Dopamine D3 receptor, Estrogen receptor 1 and 2, Glucocorticoid receptor, Histamine H1 receptor, Nuclear receptor subfamily 1 group I member 2, Opioid receptor kappa, Opioid receptor mu, cAMP-specific 35 -cyclic phosphodiesterase 4D, Prostaglandin G/H synthase 1, Progesterone receptor.

\section{Discussion}

This study describes the effect of two benzimidazole derivatives as selective LmArg inhibitors and leishmanicidal agents. These compounds have a common benzimidazole 
nucleus present in several approved drugs, most of them substituted at position 2 [29] as shown in compounds $\mathbf{1}$ and $\mathbf{2}$. Other 2-substituted benzimidazole derivatives have also shown activity as analgesics, anti-inflammatory [30] and antibacterial agents [31]. Furthermore, docking studies showed that 2, 5 (6) substituted benzimidazole derivatives are also molecules with potential as antimicrobial agents [32]. The importance of the substituents in position 2 and 5 in benzimidazole had been also reported [33]. All of the above highlights that these positions are promising for the development of new drugs.

Until now there are few studies about LmARG inhibitors, these compounds are product or transition states analogs, which do not confer selectivity towards the parasite enzyme [24]. On the other hand, in $\alpha, \alpha$-disubstituted boronic amino acid derivatives were suggested to maintain enzyme affinity while adjusting the intermolecular interactions of the $\delta$ chain, however experimental data are not yet available [24]. Nieto et al., 2018, demonstrated the leishmanicidal activity of one benzimidazole derivative, named compound 8 , against the promastigotes and amastigotes of L. mexicana $\left(\mathrm{IC}_{50}=3.25\right.$ and $0.26 \mu \mathrm{M}$, respectively). In addition, authors evaluated the inhibitory activity of compound $\mathbf{8}$ against recombinant LmARG using the Quantichom Arginase Activity Assay kit, and determined an $\mathrm{I}_{50}$ of $35.9 \mu \mathrm{M}$. Nevertheless, the difference between $\mathrm{I}_{50}$ and $\mathrm{IC}_{50}$ values, many times lower in the parasite, suggested that there are more targets for these molecules in the parasite apart from arginase [34]. To the contrary, this relationship ( $\mathrm{I}_{50}$ and $\mathrm{IC}_{50}$ values) in compounds $\mathbf{1}$ and $\mathbf{2}$ suggest that arginase could be the principal target in the parasite (Figure 1 and Table 2). Therefore, the strategy of target directed drug design was helpful to obtain molecules with, in principle, more specificity.

Interactions observed in LmARG-inhibitor complex with Asp141, Asn143, and Glu197 have been reported in other LmARG inhibitors, such as nor-NOHA, 2-(S)-amino-6-boronohexanoic acid $(\mathrm{ABH})$, and its derivatives (R)-2-amino-6-borono-2-[2-(piperidin-1-yl)ethyl]hexanoic acid (ABHPE) and (R)-2-amino-6-borono-2-[1-(3,4 dichlorobenzyl)piperidin-4-yl]-hexanoic acid (ABHDP) [15,24]. In particular, the interaction with Asp141 was also found in complexes of LaARG with quercetin, quercitrin and isoquercitrin, where the two hydroxyls in catechol group of the flavonoids formed a hydrogen bond with Asp141 [18]. Moreover, in a study of cinnamide inhibitors evaluated in LaARG, it was observed that some of these inhibitors share Van der Waals interactions with the same residues as compound 1 and 2 (His139, Val149, and His154), as well as electrostatic interactions with Asp245 and Glu288 [20]. Furthermore, several of these Van der Waals interactions were also found with chalcone inhibitors in L. infantum [22].

On the other hand, biological activity and cytotoxicity studies indicated that both LmARG inhibitors had leishmanicidal activity being compound $\mathbf{1}$ as active as the reference drug Glucantime ( 32 and $35 \mu \mathrm{M}$, respectively) and more selective against the amastigote stage of the parasite than the three reference drugs used for the treatment of leishmaniasis (Table 3). In the same context, several cinnamides derivatives were reported as LaARG inhibitors and tested against $L$. amazonensis promastigotes, but only caffeic acid phenylamide (CAPA) showed biological activity with an $\mathrm{IC}_{50}$ of $82.56 \mu \mathrm{M}$, however, no data over its effect against mammalian cell lines are available [20].

Compounds of synthetic origin such as benzophenone [35] and 5-nitroindazole derivatives have also been reported with leishmanicidal activity against $L$. infantum, L. braziliensis, and $L$. donovani and their cytotoxic effect on macrophages was also evaluated [36]. These compounds showed biological activity in the micromolar order and also exhibited selectivity, similar results as those reported in our study. Additionally, several LmARG inhibitors have been reported, nonetheless, assays in parasites only have been done with NOHA and nor-NOHA inhibitors, which showed an $\mathrm{EC}_{50}$ in the millimolar order in promastigotes [23], in comparison with compounds $\mathbf{1}$ and $\mathbf{2}$ that act in the micromolar range (Table 2). It is of interest to evaluate in future studies the leishmanicidal activity of compounds $\mathbf{1}$ and $\mathbf{2}$ against other Leishmania spp. causative of the other clinical manifestations of leishmaniasis. Altogether, the results reported in our study suggest that the two benzimidazole derivatives are an excellent starting point for design new drugs against leishmanisis. 


\section{Materials and Methods}

\subsection{Virtual Screening}

The crystal structure of LmARG in complex with inhibitor ABH (PDB ID: 4IU0) [15] was selected from the Protein Data Bank. The protein was prepared using Protein Preparation Wizard tool [37] (Schrödinger Release 2016: Glide, Schrödinger, LLC, New York, NY, USA). All unnecessary ligands and the water molecules were removed except the $\mathrm{Mn}^{2+}$ ions, which are important in enzymatic catalysis. Furthermore, in this module bond orders were assigned, hydrogens were added, and zero-order bonds to metals were created. The structure was minimized with the OPLS2005 forcefield [38,39].

Our in-house chemical library conformed by 450 benzimidazole derivatives was used for molecular docking virtual screening. Compounds were prepared using the module LigPrep (Schrödinger Release 2016: LigPrep, Schrödinger, LLC, New York, NY, USA) to generate low-energy 3D structures with ionization states of $\mathrm{pH} 7+/-0.5$ using OPLS2005 forcefield. The docking was made on the active site selecting the manganese atoms of the LmARG as center, with a grid box size of $10 \times 10 \times 10$. Docking studies were performed using Glide in its three modes, Standard Precision, Extra Precision, and Induced Fit Docking (IFD) using default parameters [40-42]. The complexes obtained from IFD were used for molecular dynamics simulation studies.

\subsection{Cloning of L. mexicana Arginase Gene}

The gen $A R G$ that encodes for arginase from L. mexicana (LmARG) was amplified using the following oligonucleotides $5^{\prime}$-GCCATATGGAGCACGTGCAGCAGTACAAGTTCTAC$3^{\prime}$ (forward) and 5'-GC-GGATCCCTATAGCTTGGAGCTCGTATGCGGAGTGTA-3' (reverse). Restriction sites for $\mathrm{NdeI}$ and $\mathrm{BamHI}$ were introduced in the forward and reverse oligonucleotides, respectively. The PCR product was cloned using PCR BLUNT II ${ }^{\circledR}$ TOPO $^{\circledR}$ vector (Invitrogen, Carlsbad, CA, USA), and then was subcloned into pET28a(+). The resulting plasmid was transformed in E. coli BL21(DE3)pLysS competent cells (Novagen, Madison, WI, USA).

\subsection{Cloning of Human Arginase 1 Gene}

The gen ARG1 that encodes for arginase 1 from human (HsARG) was amplified from HepG2 cells RNA [HEPG2] (ATCC ${ }^{\circledR}$ HB-8065 ${ }^{\mathrm{TM}}$ ) by RT-PCR using oligonucleotides 5'GCCATATGAGCGCCAAGTCCAG-3' (forward) and 5'-GGGTGGATTCATTCCTAGGCG$3^{\prime}$ (reverse). Restriction sites for NdeI and BamHI were introduced in the forward and reverse oligonucleotides, respectively. The PCR product was cloned into $\mathrm{PJET}^{\circledR}$ plasmid and then was subcloned into pETHISTEV [43]. The resulting vector was transformed in $E$. coli BL21(DE3)pLysS competent cells (Novagen, Madison, WI, USA).

\subsection{Expression and Purification of Arginases}

Bacteria transformed with recombinant plasmid were grown in Luria-Bertani medium containing $50 \mu \mathrm{g} / \mathrm{mL}$ kanamycin (LmARG) or $50 \mu \mathrm{g} / \mathrm{mL}$ ampicillin (HsARG1) at $37^{\circ} \mathrm{C}$. Once the cultures reached an $\mathrm{OD}_{600} \mathrm{~nm}$ of 0.8 , isopropyl $\beta$-D-thiogalactopyranoside (IPTG) was added $(1 \mathrm{mM})$ to induce overexpression and incubated overnight. Thereafter, cells were harvested by centrifugation at $5000 \mathrm{rpm}$ during $30 \mathrm{~min}$. The cells were resuspended in buffer A (50 mM potassium phosphate ( $\mathrm{pH} 7.0), 300 \mathrm{mM} \mathrm{NaCl}, 10 \%(v / v)$ glycerol) supplemented with the protease inhibitor PMSF $(200 \mu \mathrm{M})$ and then lysed by sonication. The lysate was centrifuged at 12,000 rpm for $30 \mathrm{~min}$. LmARG and HsARG were purified through affinity chromatography, the supernatant was loaded into a column with Ni-NTA resin pre-equilibrated in buffer A. The column was washed with buffer A supplemented with an imidazole gradient of 50, 150, and $300 \mathrm{mM}$. Both enzymes eluted in imidazole $300 \mathrm{mM}$. Protein concentrations were determined by the Bradford method [44]. 


\subsection{Enzyme Activity}

The activity of the recombinant arginases was measured in a colorimetric assay with some modifications [45]. Briefly, the enzyme $(2 \mu \mathrm{g})$ was previously activated with $1 \mathrm{mM}$ $\mathrm{MnCl}_{2}, 100 \mathrm{mM}$ Tris-HCl, $\mathrm{pH} 8$ during $15 \mathrm{~min}$ at $37^{\circ} \mathrm{C}$. Thereafter, $50 \mathrm{mM}$ L-arginine was added, and the reaction was stopped after 10 min using $30 \mu \mathrm{L}$ of an acid mixture $\left(\mathrm{H}_{2} \mathrm{SO}_{4}\right.$, $\mathrm{H}_{3} \mathrm{PO}_{4}$ and $\mathrm{H}_{2} \mathrm{O}$ [1:3:7]), and $20 \mu \mathrm{L}$ of $245 \mathrm{mM}$ of $\alpha$-isonitrosopropiophenone (dissolved in ethanol). Samples were heated in a thermocycler at $95^{\circ} \mathrm{C}$ for $1 \mathrm{~h}$. The urea in the samples was measured at $550 \mathrm{~nm}$ in a Synergy H1 Hybrid Multi-Mode Microplate Reader (BioTek).

\subsection{Inhibition Assays}

The fifty molecules with the highest docking score were selected for inhibition studies that were made under the conditions mentioned above, adding the respective compound (dissolved in DMSO) at a concentration of $200 \mu \mathrm{M}$, keeping a final 10\% DMSO concentration. The concentration that inhibits $50 \%$ of the enzyme activity $\left(I_{50}\right)$ was determined through curves at different compound concentrations. The $\mathrm{I}_{50}$ was obtained fitting the curves to the equation reported by Téllez-Valencia, et al., 2002 [25].

\subsection{Molecular Dynamics}

Molecular dynamics simulations with the following systems, Apo-LmARG, LmARGcompound-1, and LmARG-compound-2 were performed using Desmond software [46] (Schrödinger Release 2016: Desmond Molecular Dynamics System, D. E. Shaw Research, New York, NY, 2016. Maestro-Desmond Interoperability Tools, Schrödinger, New York, NY, USA). The complexes were centered in an orthorhombic box and filed with an explicit solvent using the TIP4PEW model of water. The systems were neutralized with counter ions of $\mathrm{Na}^{+}$to balance the net charges of the systems. Minimization and equilibration were simulated using the default parameters. The simulation was performed during $30 \mathrm{~ns}$ and the data were collected every $100 \mathrm{ps}$. The pressure was maintained at 1 atmosphere and temperature at $300 \mathrm{~K}$, using an NPT ensemble.

\subsection{In Silico ADME-Tox Prediction}

FAFDrugs4 [47] and ADMET-SAR [48] servers were used to predict ADME-Tox properties of compounds whilst ProTox [49] server was used for prediction of toxicities. Some of descriptors determined were molecular weight (MW), logarithm of the partition coefficient n-octanol/water $(\log \mathrm{P})$, octanol water distribution coefficient $(\log \mathrm{D})$, intrinsic water solubility $(\log S w)$, topological polar surface area (tPSA), rotable bonds (RB), hydrogen bond donors (HBD), hydrogen bond acceptors (HBA), Lipinski's rules violations, Veber Rules, Egan Rules, Predicted LD50, Predicted toxicity class, and Toxicity targets.

\subsection{Biological Activity against Leishmania mexicana Promastigotes}

Promastigotes of L. mexicana (MNYC/BZ/62/M379 reference strain) were grown in Schneider's medium supplemented with fetal bovine serum $10 \%(v / v)$, ampicillin $(100 \mathrm{U} / \mathrm{mL}) /$ streptomycin $(100 \mu \mathrm{g} / \mathrm{mL})$. Parasites were collected at log phase to assess the compounds and $5 \times 10^{5}$ promastigotes were seeded in a 96-wells plate. Compounds were previously dissolved in dimethyl sulfoxide (DMSO) up to a concentration of $1 \mathrm{mg} / \mathrm{mL}$. Thereafter, serial dilutions were made with culture medium from $100 \mu \mathrm{g} / \mathrm{mL}$ to $0.8 \mu \mathrm{g} / \mathrm{mL}$ and then they were added to the wells by triplicates. Parasites non treated and treated with Glucantime, Amphotericin B and Miltefosine were included as positive and negative controls, respectively. Parasites were incubated at $26^{\circ} \mathrm{C}$ during $48 \mathrm{~h}$ and resazurin $2.5 \mathrm{mM}$ was added at the end into each well. Afterwards, fluorescence intensity was measured with excitation/emission 535/590 $\mathrm{nm}$ in a spectrofluorometer (Infinite 200, Tecan Group Ltd., Mannedorf, Switzerland). Finally, half maximal inhibitory concentration $\left(\mathrm{IC}_{50}\right)$ was determined through a Probit analysis [50]. The assays were made by triplicate in 3 independent experiments. 


\subsection{Biological Activity against Leishmania mexicana Amastigotes}

Biological activity of the benzimidazole derivatives was also evaluated against the amastigote of L. mexicana. For this, $5 \times 10^{4}$ murine macrophages J774.2 (ATCC ${ }^{\circledR}$ TIB-67) per well were grown in a plate of 96 wells with RPMI medium at $33{ }^{\circ} \mathrm{C}, 5 \% \mathrm{CO}_{2}$ during $24 \mathrm{~h}$. The cells were infected with promastigotes in log phase in a 10:1 proportion (parasite: macrophage) and they were incubated at $37{ }^{\circ} \mathrm{C}, 5 \% \mathrm{CO}_{2}$ during $24-48 \mathrm{~h}$. A wash with RPMI medium to remove the not-infected promastigotes was made. Compounds were added in a serial dilution from $100 \mu \mathrm{g}$ to $0.8 \mu \mathrm{g} / \mathrm{mL}$ in triplicate and were incubated at $37^{\circ} \mathrm{C}, 5 \%$ $\mathrm{CO}_{2}$ for $48 \mathrm{~h}$. Glucantime, Amphotericin B and Miltefosine were used as reference drugs. Then, the cells were lysed with a non-complemented Schneider's medium lysis solution with SDS $0.01 \%$, after incubating for $20 \mathrm{~min}$ the lysis solution was removed. Afterwards, Schneider medium was added incubating at $26^{\circ} \mathrm{C}$ during four days at room temperature to differentiate intracellular amastigotes from free amastigotes. Thereafter, $20 \mu \mathrm{L}$ of resazurin $2.5 \mathrm{mM}$ was added to each well and incubated during $3 \mathrm{~h}$. Fluorescence intensity and $\mathrm{IC}_{50}$ were measured as described for promastigotes. The assays were made by triplicate in 3 independent experiments.

\subsection{Cytotoxicity Assays}

Murine macrophages J774.2 (ATCC ${ }^{\circledR}$ TIB-67) $\left(5 \times 10^{4}\right.$ cells/well) were grown in plates of 96 wells for $24 \mathrm{~h}$ at $37^{\circ} \mathrm{C}$ in $5 \% \mathrm{CO}_{2}$. Thereafter, compounds were added in serial diluted concentrations ( 100 to $0.8 \mu \mathrm{g} / \mathrm{mL}$ ) and they were incubated during $24 \mathrm{~h}$. The cellular vitality was evaluated using resazurin, adding $20 \mu \mathrm{L}$ to each well at $2.5 \mathrm{mM}$ incubating $4 \mathrm{~h}$. Finally, the cytotoxic concentration $\left(\mathrm{CC}_{50}\right)$ was determined through a Probit analysis [50]. The assays were made by triplicate in 3 independent experiments. $\mathrm{CC}_{50}$ values of Amphotericin B, Miltefosine and Glucantime were taken from a previous study [28] performed under the same conditions by our research group.

\subsection{Synthesis of Benzimidazole Derivatives}

Compounds 1,8 , and 9 were prepared from the properly substituted o-phenylenediamines, according to methods reported for our group [51-53]. Briefly, compounds 11-13 were treated with 1.2 equivalents of 1,3-dicarbomethoxy-S-methylisothiourea in $\mathrm{MeOH} / \mathrm{H}_{2} \mathrm{O}$ at $\mathrm{pH} 5$ at reflux point to give a solid which was recrystallized from methanol with activated charcoal. Scheme 1.<smiles>[R]c1cc(N)c(NC)cc1[R2]</smiles><smiles>CSC(=NC(C)=O)NC(C)=O</smiles>

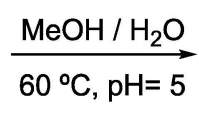

11: $\mathrm{R}_{1}=\mathrm{Cl}, \mathrm{H}$

12: $\mathrm{R}_{1}=\mathrm{H}, \mathrm{R}_{2}=\mathrm{Cl}$

13: $\mathrm{R}_{1}=\mathrm{CH}_{3}\left(\mathrm{CH}_{2}\right)_{2} \mathrm{~S}, \mathrm{R}_{2}=\mathrm{H}$<smiles>[R]c1cc2nc(NC(C)=O)n(C)c2cc1[R2]</smiles>

1: $\mathrm{R}_{1}=\mathrm{Cl}, \mathrm{R}_{2}=\mathrm{H}$

9: $\mathrm{R}_{1}=\mathrm{CH}_{3}\left(\mathrm{CH}_{2}\right)_{2} \mathrm{~S}, \mathrm{R}_{2}=\mathrm{H}$

Scheme 1. Synthesis of compounds 1, 8, 9 .

Methyl (5-chloro-1-methyl-1H-benzimidazol-2-yl)carbamate (1). Yield 85\%. Recrystallized from ethanol with charcoal. mp. 203.0-203.8 ${ }^{\circ} \mathrm{C} .{ }^{1} \mathrm{H}$ NMR (Acetone- $\left.d_{6} ; 300 \mathrm{MHz}\right) \delta$ : $3.04\left(\mathrm{~s}, 3 \mathrm{H}, \mathrm{NCH}_{3}\right), 3.17\left(\mathrm{~s}, 3 \mathrm{H}, \mathrm{OCH}_{3}\right), 6.77(\mathrm{dd}, 1 \mathrm{H}, J=8.4 \mathrm{~Hz}, J=1.8 \mathrm{~Hz}, \mathrm{H}-6), 6.94-6.98$ (m, 2H, H-4, H-7), $11.65(\mathrm{~s}, 1 \mathrm{H}, \mathrm{NH})$. MS MS $\left(\mathrm{EI}^{+}\right): m / z 239[\mathrm{M}]^{+}$.

Methyl (6-chloro-1-methyl-1H-benzimidazol-2-yl)carbamate (8). Yield 80\%. Recrystallized from ethanol $/ \mathrm{H}_{2} \mathrm{O}$ with charcoal. mp. $191.3-192.4{ }^{\circ} \mathrm{C} .{ }^{1} \mathrm{H} \mathrm{NMR}\left(\mathrm{CDCl}_{3} ; 300 \mathrm{MHz}\right) \delta$ : $3.72\left(\mathrm{~s}, 3 \mathrm{H}, \mathrm{NCH}_{3}\right), 3.82\left(\mathrm{~s}, 3 \mathrm{H}, \mathrm{OCH}_{3}\right), 7.25-7.34(\mathrm{~m}, 3 \mathrm{H}, \mathrm{H}-4, \mathrm{H}-5, \mathrm{H}-7), 9.91(\mathrm{~d}, 1 \mathrm{H}, \mathrm{NH})$. MS $\left(\mathrm{EI}^{+}\right): m / z 239[\mathrm{M}]^{+}$.

Methyl (1-methyl-5-(propylthio)-1H-benzimidazol-2-yl)carbamate (9). Yield $80 \%$. Recrystallized from methanol with charcoal. mp. 120.5-122.1 ${ }^{\circ} \mathrm{C} .{ }^{1} \mathrm{H}$ NMR (DMSO- $d_{6}$; $300 \mathrm{MHz}) \delta: 0.93\left(\mathrm{t}, 3 \mathrm{H}, J=7.5 \mathrm{~Hz}, \mathrm{CH}_{3} \mathrm{CH}_{2} \mathrm{CH}_{2} \mathrm{~S}-\right), 1.53\left(\mathrm{~m}, J=7.5 \mathrm{~Hz}, 2 \mathrm{H}, \mathrm{CH}_{3} \mathrm{CH}_{2} \mathrm{CH}_{2} \mathrm{~S}-\right.$ ), $2.85\left(\mathrm{t}, 2 \mathrm{H}, J=6.9 \mathrm{~Hz}, \mathrm{CH}_{3} \mathrm{CH}_{2} \mathrm{CH}_{2} \mathrm{~S}-\right), 3.46\left(\mathrm{~s}, 3 \mathrm{H}, \mathrm{NCH}_{3}\right), 3.60\left(\mathrm{~s}, 3 \mathrm{H} . \mathrm{OCH}_{3}\right), 7.19(\mathrm{dd}$, 
$1 \mathrm{H}, J=8.4 \mathrm{~Hz}, J=1.5 \mathrm{~Hz}, \mathrm{H}-6), 7.32(\mathrm{~d}, 1 \mathrm{H}, J=8.1 \mathrm{~Hz}, \mathrm{H}-7), 7.42$ (s, 1H, H-1), 11.98 (s, 1H, $\mathrm{NH}) .{ }^{13} \mathrm{C}$ NMR (DMSO- $\left.d_{6} ; 75 \mathrm{MHz}\right) \delta: 13.01,21.99,28.03,36.16,51.72,109.64,112.78,124.35$, $128.71,129.21,129.59,153.5,162.51 . \mathrm{MS}\left(\mathrm{FAB}^{+}\right): m / z 280\left[\mathrm{M}^{+} \mathrm{H}\right]^{+}$.

Compounds $\mathbf{2 , 3}, \mathbf{6}$, and 7 were prepared from the properly substituted $1 H$-benzimidazole2-thioles 14, 15, and 16, which were synthesized according to procedures reported by our group [52,54-56]. The synthetic methodology is resumed in Scheme 2.

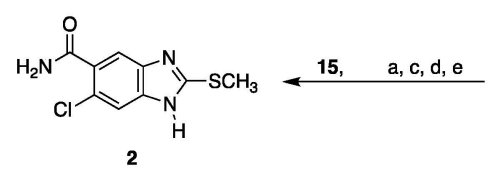

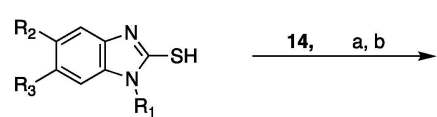

$14: \mathrm{R}_{1}=\mathrm{H}, \mathrm{R}_{2}=\mathrm{C}_{6} \mathrm{H}_{11} \mathrm{~N}_{2} \mathrm{O}, \mathrm{R}_{3}=\mathrm{Cl}$

$15: \mathrm{R}_{1}=\mathrm{H}, \mathrm{R}_{2}=\mathrm{CO}_{2} \mathrm{CH}_{3}, \mathrm{R}_{3}=\mathrm{Cl}$ $16: \mathrm{R}_{1} \mathrm{CH}_{3}, \mathrm{R}_{2}=\mathrm{Cl}_{2} \mathrm{R}_{3}=\mathrm{CO}_{2} \mathrm{CH}_{3}$

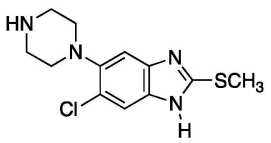

6

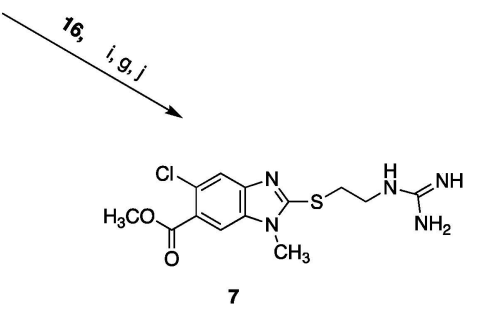

Scheme 2. Synthesis of compound 2, 3, 6 and 7. Reactants and conditions: (a) $\mathrm{CH}_{3} \mathrm{I} / \mathrm{KOH}$, acetone, $0{ }^{\circ} \mathrm{C}$; (b) EtOH $/ \mathrm{H}_{2} \mathrm{O}, \mathrm{H}_{2} \mathrm{SO}_{4}$ cat., $50{ }^{\circ} \mathrm{C}$; (c) $\mathrm{KOH}, \mathrm{MeOH}, 65{ }^{\circ} \mathrm{C}$; (d) $\mathrm{SOCl}_{2}, \mathrm{DMF}, 50{ }^{\circ} \mathrm{C}$; (e) $\mathrm{NH}_{3}, \mathrm{NH}_{4} \mathrm{OH}, \mathrm{MeCN}$, rt., 24 h; (f) bromoacetaldehyde diethyl acetal, $\mathrm{K}_{2} \mathrm{CO}_{3}, \mathrm{DMF}, \mathrm{rt} . ;(\mathrm{g}) \mathrm{HCl}$ ${ }_{2} \mathrm{~N}$, 1,4-dioxane, rt.; (h) semicarbazide hydrochloride, EtOH, $\mathrm{NaHCO}_{3}$, rt., 2 h; (i) tert-butyl (2bromoethyl)carbamate, acetone, $\mathrm{K}_{2} \mathrm{CO}_{3}$, rt.; (j) $1 \mathrm{H}$-pyrazole-1-carboxamidine hydrochloride, TEA, $\mathrm{MeCN}, 60^{\circ} \mathrm{C}, 24 \mathrm{~h}$.

Compound 2 was obtained from 15 by a series of four steps: $S$-methylation with methyl iodide, basic hydrolysis of the ester group, acyl chloride preparation with $\mathrm{SOCl}_{2}$ and DMF in catalytic quantities, and finally, the carboxamide synthesis by treatment with ammonia freshly generated in acetonitrile at room temperature [55].

Compound 6 was obtained from 14 by an $S$-methylation reaction with methyl iodide, according to our reports, and subsequent acid hydrolysis of the acetyl protecting group [52,56].

Compound 3 was obtained from 16, initially, this was converted in the 2-((2oxoethyl)thio)derivative by reaction with bromoacetaldehyde diethyl acetal followed by acid hydrolysis ( $\mathrm{HCl}$ in dioxane); then, the aldehyde was reacted with semicarbazide hydrochloride in ethanol and a base at room temperature [57]. The product was purified by recrystallization.

Compound 7 was prepared by a sequence of three reactions: preparation of 2((2-((tert-butoxycarbonyl)amino)ethyl)thio derivative by treatment 16 with tert-butyl (2bromoethyl)carbamate in acetone in a basic medium; then, the Boc protecting group was removed by hydrolysis with $\mathrm{HCl}$ in dioxane; finally, the free amine was treated with $1 \mathrm{H}$ pyrazole-1-carboxamidine hydrochloride in acetonitrile and triethylamine at $60{ }^{\circ} \mathrm{C}$ to give $7[58]$.

6-Chloro-2-(methylthio)-1H-benzimidazole-5-carboxamide (2) Yield 21\%, column chromatography $\left(\mathrm{Al}_{2} \mathrm{O}_{3}, \mathrm{EtOH}: \mathrm{MeOH}, 1: 1\right) . \mathrm{mp} 238.8-240.4{ }^{\circ} \mathrm{C} .{ }^{1} \mathrm{H}$ NMR (DMSO- $\left.d_{6} ; 400 \mathrm{MHz}\right)$ $\delta: 2.7\left(\mathrm{~s}, 3 \mathrm{H}, \mathrm{SCH}_{3}\right), 7.47\left(\mathrm{~s}, 1 \mathrm{H}, \mathrm{CONH}_{2}\right), 7.49$ (s, 1H, H-4), 7.51 (s, 1H, H-7), $7.78(\mathrm{~s}, 1 \mathrm{H}$, $\left.\mathrm{CONH}_{2}\right), 12.83(\mathrm{~s}, 1 \mathrm{H}, \mathrm{NH}) .{ }^{13} \mathrm{C}$ NMR (DMSO-d $\left.d_{6} ; 100 \mathrm{MHz}\right) \delta: 13.8,122.9,130.1,154.4$, 168.7. MS (DART $\left.{ }^{+}\right) \mathrm{m} / z: 242[\mathrm{M}+\mathrm{H}]^{+}$. HRMS $\left(\mathrm{DART}^{+}\right.$) cal. $\left[\mathrm{C}_{9} \mathrm{H}_{8} \mathrm{ClN}_{3} \mathrm{OS}+\mathrm{H}\right]$ 242.01549, found 242.01566

6-Chloro-2-(methylthio)-5-(piperazin-1-yl)-1H-benzimidazole (6). Yield $42 \%$. Purified by precipitation from ethanol/ $\mathrm{HCl}$ gas. $\mathrm{mp} 235-237^{\circ} \mathrm{C} .{ }^{1} \mathrm{H}$ NMR (DMSO- $\left.d_{6} ; 300 \mathrm{MHz}\right) \delta$ : $2.50\left(\mathrm{~s}, 3 \mathrm{H}, \mathrm{SCH}_{3}\right), 3.17-3.25(\mathrm{~m}, 8 \mathrm{H}$, piperazine), $7.32(\mathrm{~s}, 1 \mathrm{H}, \mathrm{H}-4), 7.69(\mathrm{~s}, 1 \mathrm{H}, \mathrm{H}-7), 9.42(\mathrm{~b}$, 
$2 \mathrm{H}, \mathrm{NH}) .{ }^{13} \mathrm{C}$ NMR (DMSO- $\left.d_{6} ; 75 \mathrm{MHz}\right) \delta: 14.57,43.13,48.47,105.09,114.73,124.33,132.23$, 134.64, 144.45, 153.10. MS $\left(\mathrm{EI}^{+}\right) \mathrm{m} / \mathrm{z}: 282[\mathrm{M}]^{+}$.

Methyl 2-((2-(2-carbamoylhydrazineylidene)ethyl)thio)-5-chloro-1-methyl-1Hbenzimidazole-6-carboxylate (3). Overall yield 8.37\% Recrystallized from isopropyl alcohol. mp 196.7-197.1 ${ }^{\circ} \mathrm{C} .{ }^{1} \mathrm{H}$ NMR (DMSO-d $\left.d_{6} ; 300 \mathrm{MHz}\right) \delta: 3.72\left(\mathrm{~s}, \mathrm{H}, \mathrm{NCH}_{3}\right), 3.86(\mathrm{~s}, 3 \mathrm{H}$, $\left.\mathrm{CH}_{3} \mathrm{O}\right), 4.13\left(\mathrm{~d}, 2 \mathrm{H}, J=4.7 \mathrm{~Hz}, \mathrm{SCH}_{2} \mathrm{CHN}\right), 6.21(\mathrm{sb}, \mathrm{NH}), 7.34\left(\mathrm{t}, 1 \mathrm{H}, 4.6, \mathrm{SCH}_{2} \mathrm{CHN}\right), 7.81$ (s, 1H, H-4), 7.98 (s, 1H, H-7), 10.07 (b, 1H, NH). ${ }^{13} \mathrm{C}$ NMR (DMSO-d 6 ; $\left.75 \mathrm{MHz}\right) \delta: 30.76$, $33.7,52.78,112.30,120.32,123.27,125.65,137.49,139.86,141.33,154.95,156.80,166.15$. MS $\left(\mathrm{ESI}^{+}\right): \mathrm{m} / z 378\left[\mathrm{M}^{+} \mathrm{Na}\right]^{+}$.

Methyl 5-chloro-2-((2-guanidinoethyl)thio)-1-methyl-1H-benzimidazole-6-carboxylate (7). Overall yield $37 \%$. Recrystallized from methanol. mp 172.9-173.4 ${ }^{\circ} \mathrm{C} .{ }^{1} \mathrm{H}$ NMR (DMSO$\left.d_{6} ; 400 \mathrm{MHz}\right) \delta: 3.50-3.44\left(\mathrm{~m}, 4 \mathrm{H}, \mathrm{SCH}_{2} \mathrm{CH}_{2} \mathrm{NH}\right), 3.69\left(\mathrm{~s}, 3 \mathrm{H}, \mathrm{NCH}_{3}\right), 3.85\left(\mathrm{~s}, 3 \mathrm{H}, \mathrm{CH}_{3} \mathrm{O}\right)$, 7.79 (s, 1H, H-4), 7.29 (sb, 2H, NH $), 7.54(\mathrm{sb}, 1 \mathrm{H}, \mathrm{NH}), 7.98(\mathrm{~s}, 1 \mathrm{H}, \mathrm{H}-7), 8.19(\mathrm{sb}, 1 \mathrm{H}, \mathrm{NH})$. ${ }^{13} \mathrm{C}$ NMR (DMSO- $d_{6}$; $\left.100 \mathrm{MHz}\right) \delta: 30.4,30.8,40.5,52.3,112.2,120.4,123.2,125.8,139.0,141.2$, 155.7, 157.5, 166.4. MS $\left(\mathrm{ESI}^{+}\right): \mathrm{m} / z 342[\mathrm{M}+\mathrm{H}]^{+}$.

On the other hand, the synthesis of compounds 4,5 , and 10 have already been reported by our group [59].

\subsection{Statistical Analysis}

Analysis of the MD data, specifically RMSF, was carried out by an ANOVA test using SPSS v15.0 software. Differences between data were considered statistically significant when a $p$-value $<0.05$.

\section{Conclusions}

Two novel benzimidazole derivatives (compounds 1 and 2) were discovered through virtual screening as the first selective LmARG inhibitors. Moreover, showed activity against the promastigote and amastigote stage of L. mexicana in the micromolar range. Compound $\mathbf{1}$ showed a higher Selectivity Index against the parasite amastigote than the reference drugs. Furthermore, the in silico prediction of their ADME-Tox properties suggested that both inhibitors supports the structural characteristics to be considered drug candidates. Therefore, the compounds reported here provides a starting point to develop more powerful and selective LmARG inhibitors to continue in the search of new drugs against leishmaniasis.

Supplementary Materials: The following are available online at https:/ / www.mdpi.com/article/10 $.3390 /$ ijms222413613/s1.

Author Contributions: Conceptualization, C.A.-D. and A.T.-V.; methodology, I.B.-C., A.H.-C., R.C., L.Y.-M., J.O.-H., S.T.M., E.S.-C., A.R.-M., S.M.-C., C.A.-D. and A.T.-V.; formal analysis I.B.-C., A.H.-C., R.C., L.Y.-M., E.S.-C., M.V.-S. and J.A.H.; writing-original draft preparation, I.B.-C.; writing-review and editing, C.A.-D., A.H.-C., R.C., L.Y.-M., J.O.-H., E.S.-C., M.V.-S., J.A.H., A.R.-M.; and A.T.-V.; funding acquisition, J.A.H.; A.T.-V. and C.A.-D. All authors have read and agreed to the published version of the manuscripts.

Funding: This research was funded by the Consejo Nacional de Ciencia y Tecnología (CONACyT), grants 257848 (A.T.-V.) and 258694 (C.A.-D.). The work in Spain was funded by a grant from the Spanish Ministry of Science, Innovation and Competitiveness PID2020-115331GB-100 to J.A.-H.

Acknowledgments: I.B.-C. acknowledge Consejo Nacional de Ciencia y Tecnología (CONACyT) for the Ph.D. fellowship granted. (No. 521238).

Conflicts of Interest: The authors declare no conflict of interest.

\section{References}

1. Reithinger, R.; Dujardin, J.C. Molecular Diagnosis of Leishmaniasis: Current Status and Future Applications. J. Clin. Microbiol. 2007, 45, 21-25. [CrossRef]

2. Schriefer, A.; Wilson, M.E.; Carvalho, E.M. Recent Developments Leading toward a Paradigm Switch in the Diagnostic and Therapeutic Approach to Human Leishmaniasis. Curr. Opin. Infect. Dis. 2008, 21, 483-488. [CrossRef] 
3. World Health Organization Leishmaniasis. Available online: https://www.who.int/news-room/fact-sheets/detail/ leishmaniasis (accessed on 9 February 2021).

4. Croft, S.L.; Olliaro, P. Leishmaniasis Chemotherapy-Challenges and Opportunities. Clin. Microbiol. Infect. 2011, 17, 1478-1483. [CrossRef]

5. Mohapatra, S. Drug Resistance in Leishmaniasis: Newer Developments. Trop. Parasitol. 2014, 4, 4-9. [CrossRef]

6. Bray, P.G.; Barrett, M.P.; Ward, S.A.; de Koning, H.P. Pentamidine Uptake and Resistance in Pathogenic Protozoa: Past, Present and Future. Trends Parasitol. 2003, 19, 232-239. [CrossRef]

7. Ghorbani, M.; Farhoudi, R. Leishmaniasis in Humans: Drug or Vaccine Therapy? Drug Des. Dev. Ther. 2018, 12, 25-40. [CrossRef]

8. Rijal, S.; Ostyn, B.; Uranw, S.; Rai, K.; Bhattarai, N.R.; Dorlo, T.P.C.; Beijnen, J.H.; Vanaerschot, M.; Decuypere, S.; Dhakal, S.S.; et al. Increasing Failure of Miltefosine in the Treatment of Kala-Azar in Nepal and the Potential Role of Parasite Drug Resistance, Reinfection, or Noncompliance. Clin. Infect. Dis. 2013, 56, 1530-1538. [CrossRef]

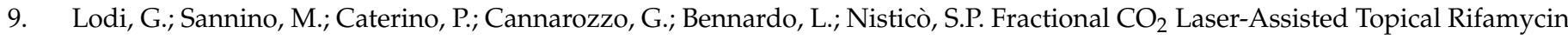
Drug Delivery in the Treatment of Pediatric Cutaneous Leishmaniasis. Pediatric Dermatol. 2021, 38, 1-4. [CrossRef]

10. Ponte-sucre, A.; Gamarro, F.; Dujardin, J.; Barrett, M.P.; Garc1, R.; Pountain, A.W.; Mwenechanya, R.; Papadopoulou, B. Drug Resistance and Treatment Failure in Leishmaniasis: A 21st Century Challenge. PLoS Negl. Trop. Dis. 2017, 11, 1-24. [CrossRef]

11. Heby, O.; Persson, L.; Rentala, M. Targeting the Polyamine Biosynthetic Enzymes: A Promising Approach to Therapy of African Sleeping Sickness, Chagas' Disease, and Leishmaniasis. Amino Acids 2007, 33, 359-366. [CrossRef]

12. Ilari, A.; Fiorillo, A.; Genovese, I.; Colotti, G. Polyamine-Trypanothione Pathway:An Update. Future Med. Chem. 2017, 9, 61-77. [CrossRef]

13. Reguera, R.M.; Balaña-Fouce, R.; Showalter, M.; Hickerson, S.; Beverley, S.M. Leishmania Major Lacking Arginase (ARG) Are Auxotrophic for Polyamines but Retain Infectivity to Susceptible BALB/c Mice. Mol. Biochem. Parasitol. 2009, 165, 48-56. [CrossRef]

14. Colotti, G.; Ilari, A. Polyamine Metabolism in Leishmania: From Arginine to Trypanothione. Amino Acids 2011, 40, 269-285. [CrossRef] [PubMed]

15. D'Antonio, E.L.; Ullman, B.; Roberts, S.C.; Dixit, U.G.; Wilson, M.E.; Hai, Y.; Christianson, D.W. Crystal Structure of Arginase from Leishmania Mexicana and Implications for the Inhibition of Polyamine Biosynthesis in Parasitic Infections. Arch. Biochem. Biophys. 2013, 535, 163-176. [CrossRef]

16. Roberts, S.C.; Tancer, M.J.; Polinsky, M.R.; Michael Gibson, K.; Heby, O.; Ullman, B. Arginase Plays a Pivotal Role in Polyamine Precursor Metabolism in Leishmania: Characterization of Gene Deletion Mutants. J. Biol. Chem. 2004, 279, 23668-23678. [CrossRef]

17. da Silva, E.R.; Boechat, N.; Pinheiro, L.C.S.; Bastos, M.M.; Costa, C.C.P.; Bartholomeu, J.C.; da Costa, T.H. Novel Selective Inhibitor of Leishmania (Leishmania) Amazonensis Arginase. Chem. Biol. Drug Des. 2015, 86, 969-978. [CrossRef]

18. da Silva, E.R.; Maquiaveli, C.d.C.; Magalhães, P.P. The Leishmanicidal Flavonols Quercetin and Quercitrin Target Leishmania (Leishmania) Amazonensis Arginase. Exp. Parasitol. 2012, 130, 183-188. [CrossRef]

19. dos Reis, M.B.G.; Manjolin, L.C.; Maquiaveli, C.D.C.; Santos-Filho, O.A.; da Silva, E.R. Inhibition of Leishmania (Leishmania) Amazonensis and Rat Arginases by Green Tea EGCG, (+)-Catechin and (-)-Epicatechin: A Comparative Structural Analysis of Enzyme-Inhibitor Interactions. PLoS ONE 2013, 8, e78387.

20. da Silva, E.R.; Come, J.A.A.D.S.S.; Brogi, S.; Calderone, V.; Chemi, G.; Campiani, G.; Oliveira, T.M.F.D.S.; Pham, T.N.; Pudlo, M.; Girard, C.; et al. Cinnamides Target Leishmania Amazonensis Arginase Selectively. Molecules 2020, 25, 5271. [CrossRef]

21. Garcia, A.R.; Oliveira, D.M.P.; Claudia, F.; Amaral, A.; Jesus, J.B.; Rennó Sodero, A.C.; Souza, A.M.T.; Supuran, C.T.; Vermelho, A.B.; Rodrigues, I.A.; et al. Leishmania Infantum Arginase: Biochemical Characterization and Inhibition by Naturally Occurring Phenolic Substances. J. Enzym. Inhib. Med. Chem. 2019, 34, 1100-1109. [CrossRef]

22. Garcia, A.R.; Oliveira, D.M.P.; Jesus, J.B.; Souza, A.M.T.; Sodero, A.C.R.; Vermelho, A.B.; Leal, I.C.R.; Souza, R.O.M.A.; Miranda, L.S.M.; Pinheiro, A.S.; et al. Identification of Chalcone Derivatives as Inhibitors of Leishmania Infantum Arginase and Promising Antileishmanial Agents. Front. Chem. 2021, 8, 624678. [CrossRef]

23. Riley, E.; Roberts, S.C.; Ullman, B. Inhibition Profile of Leishmania Mexicana Arginase Reveals Differences with Human Arginase I. Int. J. Parasitol. 2011, 41, 545-552. [CrossRef]

24. Hai, Y.; Christianson, D.W. Crystal Structures of Leishmania Mexicana Arginase Complexed with $\alpha, \alpha$-Disubstituted Boronic Amino-Acid Inhibitors. Acta Crystallogr. Sect. F Struct. Biol. Commun. 2016, 72, 300-306. [CrossRef]

25. Tellez-Valencia, A.; Avila-Ríos, S.A.; Perez-Montfort, R.; Rodríguez-Romero, A.; Tuena de Gomez-Puyou, M.; Lopez-Calahorra, F.; Gomez-Puyou, A. Highly Specific Inactivation of Triosephosphate Isomerase from Trypanosoma Cruzi. Biochem. Biophys. Res. Commun. 2002, 295, 958-963. [CrossRef]

26. Vázquez-Raygoza, A.; Cano-González, L.; Velázquez-Martínez, I.; Trejo-Soto, P.J.; Castillo, R.; Hernández-Campos, A.; HernándezLuis, F.; Oria-Hernández, J.; Castillo-Villanueva, A.; Avitia-Domínguez, C.; et al. Species-Specific Inactivation of Triosephosphate Isomerase from Trypanosoma Brucei: Kinetic and Molecular Dynamics Studies. Molecules 2017, 22, 2055. [CrossRef]

27. Mortier, J.; Prévost, J.R.C.; Sydow, D.; Teuchert, S.; Omieczynski, C.; Bermudez, M.; Frédérick, R.; Wolber, G. Arginase Structure and Inhibition: Catalytic Site Plasticity Reveals New Modulation Possibilities. Sci. Rep. 2017, 7, 13616. [CrossRef]

28. Matadamas-Martínez, F.; Hernández-Campos, A.; Téllez-Valencia, A.; Vázquez-Raygoza, A.; Comparán-Alarcón, S.; Yépez-Mulia, L.; Castillo, R. Leishmania Mexicana Trypanothione Reductase Inhibitors: Computational and Biological Studies. Molecules 2019, 24, 3216. [CrossRef] 
29. Vitaku, E.; Smith, D.T.; Njardarson, J.T. Analysis of the Structural Diversity, Substitution Patterns, and Frequency of Nitrogen Heterocycles among U.S. FDA Approved Pharmaceuticals. J. Med. Chem. 2014, 57, 10257-10274. [CrossRef]

30. Mariappan, G.; Hazarika, R.; Alam, F.; Karki, R.; Patangia, U.; Nath, S. Synthesis and Biological Evaluation of 2-Substituted Benzimidazole Derivatives. Arab. J. Chem. 2015, 8, 715-719. [CrossRef]

31. Chintakunta, R.; Meka, G. Synthesis, in Silico Studies and Antibacterial Activity of Some Novel 2-Substituted Benzimidazole Derivatives. Future J. Pharm. Sci. 2020, 6, 10921-10945. [CrossRef]

32. Aroso, R.T.; Guedes, R.C.; Pereira, M.M. Synthesis of Computationally Designed 2,5(6)-Benzimidazole Derivatives via PdCatalyzed Reactions for Potential E. Coli DNA Gyrase B Inhibition. Molecules 2021, 26, 1326. [CrossRef] [PubMed]

33. Shah, K.; Chhabra, S.; Shrivastava, S.K.; Mishra, P. Benzimidazole: A Promising Pharmacophore. Med. Chem. Res. 2013, 22, 5077-5104. [CrossRef]

34. Nieto-Meneses, R.; Castillo, R.; Hernández-Campos, A.; Maldonado-Rangel, A.; Matius-Ruiz, J.B.; Trejo-Soto, P.J.; Nogueda-Torres, B.; Dea-Ayuela, M.A.; Bolás-Fernández, F.; Méndez-Cuesta, C.; et al. In Vitro Activity of New N-Benzyl-1H-Benzimidazol2-Amine Derivatives against Cutaneous, Mucocutaneous and Visceral Leishmania Species. Exp. Parasitol. 2018, 184, 82-89. [CrossRef]

35. de Almeida, L.; Alves, K.F.; Maciel-Rezende, C.M.; Jesus, L.D.O.P.; Pires, F.R.; Junior, C.V.; Izidoro, M.A.; Júdice, W.A.D.S.; dos Santos, M.H.; Marques, M.J. Benzophenone Derivatives as Cysteine Protease Inhibitors and Biological Activity against Leishmania (L.) Amazonensis Amastigotes. Biomed. Pharmacother. 2015, 75, 93-99. [CrossRef]

36. Martín-Montes, Á.; Aguilera-Venegas, B.; Ma Morales-Martín, R.; Martín-Escolano, R.; Zamora-Ledesma, S.; Marín, C.; Arán, V.J.; Sánchez-Moreno, M. In Vitro Assessment of 3-Alkoxy-5-Nitroindazole-Derived Ethylamines and Related Compounds as Potential Antileishmanial Drugs. Bioorganic Chem. 2019, 92, 103274. [CrossRef] [PubMed]

37. Madhavi Sastry, G.; Adzhigirey, M.; Day, T.; Annabhimoju, R.; Sherman, W. Protein and Ligand Preparation: Parameters, Protocols, and Influence on Virtual Screening Enrichments. J. Comput. Aided Mol. Des. 2013, 27, 221-234. [CrossRef]

38. Shivakumar, D.; Williams, J.; Wu, Y.; Damm, W.; Shelley, J.; Sherman, W. Prediction of Absolute Solvation Free Energies Using Molecular Dynamics Free Energy Perturbation and the Opls Force Field. J. Chem. Theory Comput. 2010, 6, 1509-1519. [CrossRef] [PubMed]

39. Jorgensen, W.L.; Maxwell, D.S.; Tirado-Rives, J. Development and Testing of the OPLS All-Atom Force Field on Conformational Energetics and Properties of Organic Liquids. J. Am. Chem. Soc. 1996, 118, 11225-11236. [CrossRef]

40. Friesner, R.A.; Murphy, R.B.; Repasky, M.P.; Frye, L.L.; Greenwood, J.R.; Halgren, T.A.; Sanschagrin, P.C.; Mainz, D.T. Extra Precision Glide: Docking and Scoring Incorporating a Model of Hydrophobic Enclosure for Protein-Ligand Complexes. J. Med. Chem. 2006, 49, 6177-6196. [CrossRef]

41. Halgren, T.A.; Murphy, R.B.; Friesner, R.A.; Beard, H.S.; Frye, L.L.; Pollard, W.T.; Banks, J.L. Glide: A New Approach for Rapid, Accurate Docking and Scoring. 2. Enrichment Factors in Database Screening. J. Med. Chem. 2004, 47, 1750-1759. [CrossRef]

42. Friesner, R.A.; Banks, J.L.; Murphy, R.B.; Halgren, T.A.; Klicic, J.J.; Mainz, D.T.; Repasky, M.P.; Knoll, E.H.; Shelley, M.; Perry, J.K.; et al. Glide: A New Approach for Rapid, Accurate Docking and Scoring. 1. Method and Assessment of Docking Accuracy. J. Med. Chem. 2004, 47, 1739-1749. [CrossRef] [PubMed]

43. Hernández-Alcántara, G.; Torres-Larios, A.; Enríquez-Flores, S.; García-Torres, I.; Castillo-Villanueva, A.; Méndez, S.T.; de la Mora-de la Mora, I.; Gómez-Manzo, S.; Torres-Arroyo, A.; López-Velázquez, G.; et al. Structural and Functional Perturbation of Giardia Lamblia Triosephosphate Isomerase by Modification of a Non-Catalytic, Non-Conserved Region. PLoS ONE 2013, 8 , e69031. [CrossRef]

44. Bradford, M.M. A Rapid and Sensitive Method for the Quantitation of Microgram Quantities of Protein Utilizing the Principle of Protein-Dye Binding. Anal. Biochem. 1976, 72, 248-254. [CrossRef]

45. Corraliza, I.M.; Campo, M.L.; Soler, G.; Modolell, M. Determination of Arginase Activity in Macrophages: A Micromethod. J. Immunol. Methods 1994, 174, 231-235. [CrossRef]

46. Bowers, K.J.; Chow, D.E.; Xu, H.; Dror, R.O.; Eastwood, M.P.; Gregersen, B.A.; Klepeis, J.L.; Kolossvary, I.; Moraes, M.A.; Sacerdoti, F.D.; et al. Scalable Algorithms for Molecular Dynamics Simulations on Commodity Clusters. In Proceedings of the SC '06: 2006 ACM/IEEE Conference on Supercomputing, Tampa, FL, USA, 11-17 November 2006; p. 43.

47. Lagorce, D.; Bouslama, L.; Becot, J.; Miteva, M.A.; Villoutreix, B.O. FAF-Drugs4: Free ADME-Tox Filtering Compu-Tations for Chemical Biology and Early Stages Drug Discovery. Bioinformatics 2017, 33, 3658-3660. [CrossRef] [PubMed]

48. Cheng, F.; Li, W.; Zhou, Y.; Shen, J.; Wu, Z.; Liu, G.; Lee, P.W.; Tang, Y. AdmetSAR: A Comprehensive Source and Free Tool for Assessment of Chemical ADMET Properties. J. Chem. Inf. Modeling 2012, 52, 3099-3105. [CrossRef] [PubMed]

49. Drwal, M.N.; Banerjee, P.; Dunkel, M.; Wettig, M.R.; Preissner, R. ProTox: A Web Server for the in Silico Prediction of Rodent Oral Toxicity. Nucleic Acids Res. 2014, 42, 53-58. [CrossRef]

50. Pum, J. A Practical Guide to Validation and Verification of Analytical Methods in the Clinical Laboratory. Adv. Clin. Chem. 2019, 90, 215-281.

51. Soria-Arteche, O.; Castillo, R.; Hernández-Campos, A.; Hurtado-De La Peña, M.; Navarrete-Vázquez, G.; Luis Medina-Franco, J.; Gómez-Flores, K. Studies on the Selective S-Oxidation of Albendazole, Fenbendazole, Triclabendazole, and Other Benzimidazole Sulfides. J. Mex. Chem. Soc. 2005, 49, 353-358. 
52. Soria-Arteche, O.; Hernández-Campos, A.; Yépez-Mulia, L.; Trejo-Soto, P.J.; Hernández-Luis, F.; Gres-Molina, J.; Maldonado, L.A.; Castillo, R. Synthesis and Antiprotozoal Activity of Nitazoxanide-N-Methylbenzimidazole Hybrids. Bioorganic Med. Chem. Lett. 2013, 23, 6838-6841. [CrossRef] [PubMed]

53. Valdez, J.; Cedillo, R.; Hernandez-Campos, A.; Yepez, L.; Hernandez-Luis, F.; Navarrete-Vazquez, G.; Tapia, A.; Cortes, R.; Hernandez, M.; Castillo, R. Synthesis and Antiparasitic Activity of $1 \mathrm{H}$-Benzimidazole Derivatives. Bioorganic Med. Chem. Lett. 2002, 12, 2221-2224. [CrossRef]

54. Trejo-Soto, P.; Flores-Gahona, A.; Castillo, R.; Hernández-Campos, A. Simplifying Nucleophilic Aromatic Substitutions: Microwave-Assisted Solvent Free Synthesis of 5-Alkylamino-2-Nitroanilines. Curr. Microw. Chem. 2016, 3, 258-265. [CrossRef]

55. Flores-Carrillo, P.; Velázquez-López, J.M.; Aguayo-Ortiz, R.; Hernández-Campos, A.; Trejo-Soto, P.J.; Yépez-Mulia, L.; Castillo, R. Synthesis, Antiprotozoal Activity, and Chemoinformatic Analysis of 2-(Methylthio)-1H-Benzimidazole-5-Carboxamide Derivatives: Identification of New Selective Giardicidal and Trichomonicidal Compounds. Eur. J. Med. Chem. 2017, 137, 211-220. [CrossRef]

56. Velázquez-López, J.M.; Hernández-Campos, A.; Yépez-Mulia, L.; Téllez-Valencia, A.; Flores-Carrillo, P.; Nieto-Meneses, R.; Castillo, R. Synthesis and Trypanocidal Activity of Novel Benzimidazole Derivatives. Bioorganic Med. Chem. Lett. 2016, 26, 4377-4381. [CrossRef]

57. Mikhaleva, A.I.; Ivanov, A.V.; Vasil'tsov, A.M.; Ushakov, I.A.; Shi Ma, J.; Yang, G. Directed Synthesis of Semicarbazones, Thiosemicarbazones, and Guanylhydrazones of 1-Vinylpyrrole-2-Carbaldehydes. Chem. Heterocycl. Compd. 2008, 44, 1384-1390. [CrossRef]

58. Bernatowicz, M.S.; Wu, Y.; Matsueda, G.R. 1H-Pyrazole-1-Carboxamidine Hydrochloride an Attractive Reagent for Guanylation of Amines and Its Application to Peptide Synthesis. J. Org. Chem. 1992, 57, 2497-2502. [CrossRef]

59. Valdez-Padilla, D.; Rodríguez-Morales, S.; Hernández-Campos, A.; Hernández-Luis, F.; Yépez-Mulia, L.; Tapia-Contreras, A.; Castillo, R. Synthesis and Antiprotozoal Activity of Novel 1-Methylbenzimidazole Derivatives. Bioorganic Med. Chem. 2009, 17, 1724-1730. [CrossRef] [PubMed] 